\title{
EURÓPA KOLLÉGIUM EGYETEMISTA KÖZPONT
}

Európa Kollégium Egyetemista Központ

Cím: Újvidék, Cirill és Metód utca 11.

Honlap: https://europakollegium.com

E-mail: office@eukol.rs

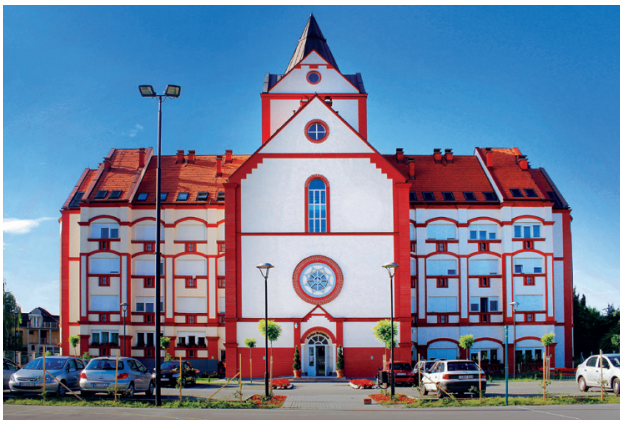

Az Európa Kollégium Egyetemista Központ 2015 szeptemberében kezdte meg működését Újvidéken, azzal az elsődleges céllal, hogy otthont nyújtson a tartományi székvárosban tanuló magyar anyanyelvű vajdasági hallgatók számára.

Az Európa Kollégium küldetése, hogy a fiatalok számára segítséget nyújtson tudásuk gyarapításában, és ezáltal hozzájáruljon a Vajdaság Autonóm Tartományban élő magyar nemzeti közösséghez tartozók oktatási szintjének növeléséhez. Az Európa Kollégium nemcsak egyedülálló szakkollégium, hanem a vajdasági magyarság szellemi, tudományos és múvészeti központja is kíván lenni.

Az Európa Kollégium működtetésével széles körű lehetőségek nyíltak az újvidéki felsőoktatási intézményekben tanuló vajdasági magyar nemzetiségű fiatalok számára. Ezek elsősorban a bentlakási és közösségi lehetőségekben, valamint az intézmény megnyitásával párhuzamosan beindított, és azóta is folyamatosan fejlődő szakkollégiumi programokban nyilvánulnak meg. Ezeket a programokat a nevelőtanárok irányítják a magyarországi szakkollégiumi intézményekhez hasonlóan. Ennek keretében múhelymunkák, közéleti és kulturális események, valamint szakmai előadások kerülnek megszervezésre.

Az Európa Kollégium 2017 óta biztosít kollégistáinak elektronikus adatbázisokhoz való hozzáférést, ami a szerbiai Magyar Nemzeti Tanács indítványára és közreműködésével, valamint a Magyar Nemzeti Bank Pallas Athéné alapítványai támogatásával valósult meg. A kollégium 2018-ban csatlakozott az MTA Könyvtár és Információs Központban müködő Elektronikus Információszolgáltatás Nemzeti

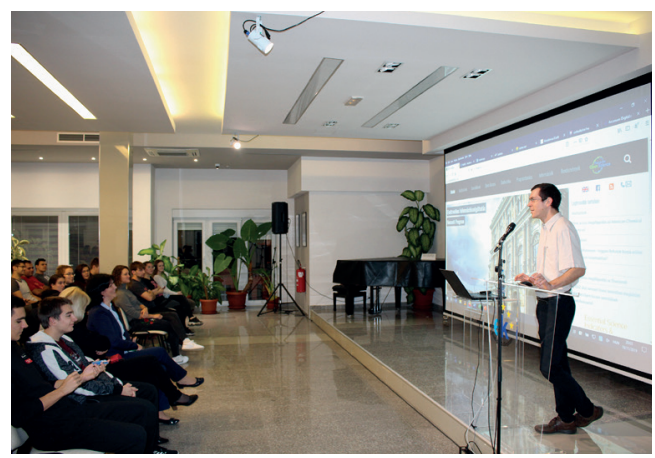




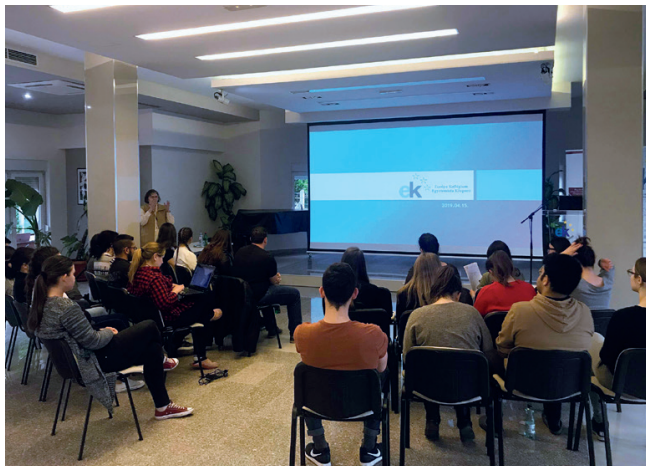

Program (EISZ) konzorciumi hálózatához. Az Innovációs és Technológiai Minisztérium égisze alatt múködő Nemzeti Kutatási, Fejlesztési és Innovációs Hivatal 2019-től fedezi céltámogatás keretében az Európa Kollégiumban elérhető elektronikus adatbázisok költségeit az EISZ-en keresztül. Így az elektronikus folyóiratok mellett 2019-től immár elektronikus könyveket és szótárakat is böngészhetnek a kollégisták a kollégium hálózatán keresztül. Az adatbázisok használata a kollégiumban 2018 és 2019 folyamán elérte egy átlagos magyarországi könyvtár vagy kutatóintézet szintjét.

Az Európa Kollégium kollégistái elsősorban a szakkollégiumi műhelymunkák keretében elkészített szakdolgozataik megírásánál veszik igénybe az elektronikus adatbázisokat, de már jelentős számban használják egyetemi tanulmányaikhoz, illetve kikapcsolódás, múvelődés céljából is.

Igazgató: Snejder-Sára Ildikó

EISZ kapcsolattartó: Kovács Birkás Zsolt 